\title{
TOUCHING FREUD'S DOG
}

\section{H.D.'s Tactile Poetics}

\author{
Sarah Jackson
}

ABSTRACT: "Do not touch me", Frau Emmy warns Freud in 1889. "Do not touch", Freud echoes in 1933. This time, he is referring to his pet chow, Yofi, warning H.D. that "she snaps - she is very difficult with strangers". Examining the prohibition in light of work by Jacques Derrida and Jean-Luc Nancy, this article charts the withdrawal that always interrupts touch. Despite Freud's taboo, however, H.D.'s writing seeks to make contact in strange and unnerving ways. Developing Julia Kristeva's account of the semiotic, this paper proposes a literature of touch. Reading H.D.'s poems, alongside Tribute to Freud, and her letters, the author demonstrates that H.D.s poetics are always haunted by the very (im)possibility of contact.

KEYWORDS: touch; poetics; H.D.; psychoanalysis; Jacques Derrida; Jean-Luc Nancy

Do not touch ... 1

It is not the first thing, but it is the second: "Do not touch," Sigmund Freud says to H.D. upon her entering analysis. ${ }^{2} \mathrm{He}$ is referring to his pet chow, Yofi, warning H.D. that "she snaps - she is very difficult with strangers" (98). H.D., however, challenges Freud's word of caution, and "not only continue[s] [her] gesture toward the little chow, but crouch[es] on the floor so that she can snap better if she wants to" (98). Freud's prohibition of touch and H.D.'s challenge to it - a challenge that I propose is extended in and through her writing - perform a tactile poetics, a literature of touch.

In this paper I explore Freud's warning in light of work by Jacques Derrida (On Touching) and Jean-Luc Nancy (Noli Me Tangere). Touch is always already permeated by its own interruption, requiring a handful of tact. Despite this, H.D.'s 
writing demonstrates a heightened sense of tactility - an attempt to make contact in new and often subversive ways. Here, I examine the ways in which H.D. performs a "remote touch" in her poetry. Indeed, it is the conflict between the prohibition and the desire to touch that forms the heart of this essay, in which I try to touch touch, to reach towards the untouchable, and to tender a tactile poetics.

“Do not touch," Freud says. We've heard it before: “'Keep still! - Don't say anything! - Don't touch me!"” Frau Emmy von N. warned Freud in $1889^{3}$ - a statement that Freud appropriates in his first encounter with H.D., according to her Tribute to Freud:

A little lion-like creature came padding toward me - a lioness, as it happened. She had emerged from the inner sanctum or manifested from under or behind the couch; anyhow, she continued her course across the carpet. Embarrassed, shy, overwhelmed, I bend down to greet this creature. But the Professor says, "Do not touch her - she snaps - she is very difficult with strangers." (98)

H.D., however, does touch, and so, moreover, does Freud. During his early practice, he would press his finger on a client's forehead and massage the neck and head to facilitate release. ${ }^{4}$ His treatment of Frau Emmy, for instance, involved "warm baths, massage twice a day and hypnotic suggestion" - acts that are accompanied by "strok[ing] her several times over the eyes" (SE II: 51, 53). He repeats this stroking to relieve her gastric pains a day later, despite her ongoing injunctions, "Keep Still! Don't say anything! - Don't touch me!" (54). ${ }^{5}$ Perhaps Freud eventually responded to Frau Emmy's pleas, however, because he moved away from this early technique towards the psychoanalytic method - and the rule of abstinence. As Ernest Jones remarks, "The patient should be kept in a state of abstinence of unrequited love. The more affection you allow him, the more readily you reach his complexes, but the less definite the result." For Didier Anzieu, French psychoanalyst and author of The Skin $E g o$, the perceived risk of eroticisation, especially during his work with hysterical women and girls, led Freud to develop his technique towards the psychoanalytic method, where he "suspended all tactile contact with the patient in favour of purely linguistic exchange."7 "The tactile," writes Anzieu, "is fundamental only on condition 
that, at the necessary moment, it is prohibited" (140) - a double prohibition, in fact, that stresses the dangers of violence and of eroticisation implicit in contact.

Touch, it seems, is inhabited by the prohibition at its heart, and this "law of tact," as Derrida calls it, ${ }^{8}$ pervades our everyday professional, social and familial exchanges, extending to the psychoanalytic setting where touching is particularly taboo. This non-touching culture is everywhere and yet visible nowhere - touching tempered as if by a law of sensible handshakes. "Do not touch," we are warned in museums;

"Breakages will be paid for"; "Beware - wet paint"; and "Keep off the grass." Do not touch your father-mother-sister-brother, we are told; do not even touch yourself. Touch is taboo. Addressing the taboos attached to the treatment of enemies, of chiefs or kings and of the dead, Freud explicitly links taboo and touch in Totem and Taboo, arguing that "We cannot be surprised at the fact that, in the restrictions of taboo, touching plays a part similar to the one which it plays in 'touching phobias', though the secret meaning of the prohibition cannot be of such a specialized nature in taboo as it is in the neurosis" (SE XIII: 33). Describing the clinical history of such a case of "touching phobia" or "délire du toucher," Freud states that in very early childhood,

the patient shows a strong desire to touch, the aim of which is of a far more specialized kind than one would have been inclined to expect. This desire is promptly met by an external prohibition against carrying out that particular kind of touching. (29)

"Both the desire and the prohibition" of this particular kind of touch, Freud remarks in a footnote, "relate to the child's touching of his own genitals" (29 n. 1). He continues by explaining that the prohibition is accepted because "it finds support from powerful internal forces" and because it is "stronger than the instinct which is seeking to express itself in the touching" (29). Rather than "abolishing the instinct," however, "its only result is to repress the instinct (the desire to touch) and banish it into the unconscious" (29). Hence, "a situation is created which remains undealt with - a psychical fixation - and everything else follows from the continuing conflict between the prohibition and the instinct" (29). All our future "contact" - with ourselves and with other people - is determined by the tension between the desire and fear of touch. 
The taboo is reiterated in Christ's prohibition: "Noli me tangere," or "Touch me not," Jesus says to Mary Magdalene after his resurrection. ${ }^{9}$ For Jean-Luc Nancy, "Noli me tangere - 'Do not touch me' - calls to mind a prohibition of contact, a question of sensuality or violence, a recoil, a frightened or modest flight." ${ }^{10}$ Nancy goes on to suggest:

"Don't touch me" is a phrase that touches and that cannot touch, even when isolated in every context. It says something about touching in general, or it touches on the sensitive point of touching: on this sensitive point that touching constitutes par excellence (it is, in sum, "the" point of the sensitive) and on what forms the sensitive point within it. But this point is precisely the point where touching does not touch and where it must not touch in order to carry out its touch (its art, its tact, its grace): the point or the space without dimension that separates what touching gathers together, the line that separates the touching from the touched and thus the touch from itself. (13)

The phrase "Don't touch me" touches the heart of tactility - its implicit untouchability. Noli me tangere uncovers untouchability, its most "sensitive point" (13). The prohibition is further problematised by its difficult translation from the original Greek version, "Mè mou haptou," which carries the implied alternative, "Do not hold me back"; “"Do not hold me back"” (15), Nancy argues, "amounts to saying 'Touch me with a real touch, one that is restrained, nonappropriating and nonidentifying.' Caress me, don't touch me" (49-50). Thus, to say "Do not touch me" appears to carry "discord at the very site of the embrace" (54); it is a prohibition on touch that touches on the jouissance - the pain and the pleasure, the prohibition and the desire, the invitation and the withdrawal - of contact.

The taboo on touch, then, is Janus-faced. The word "taboo," Freud tells us, "diverges in two contrary directions"; "it means, on the one hand, 'sacred', 'consecrated', and on the other 'uncanny', 'dangerous', 'forbidden', 'unclean"' (SE XIII: 18). Touch, in a similar fashion, has an antithetical resonance; at the same time as it is prohibited and feared it is revered for its healing potential - the laying on of hands, the "Midas touch," the "Royal touch." Certainly, the healing powers inherent in Christ's touch are clear: "And he stretched out his hand and touched him, saying ... 'I wish it; be clean.' And immediately his leprosy was cleansed."11 Derrida notes that Jesus "the savior is 'touching,' he is the One who touches, and most often with his hand, and most often 
in order to purify, heal, or resuscitate - save, in a word" (On Touching 100). Touch is both reparative and threatening.

We might continue touching on touch, caressing it, perhaps even tampering with it, but I wish to turn or return, now, to the re-enactment of Christ's utterance by Freud in H.D.'s tribute. Noli me tangere, I suggest, is simultaneously performed and displaced by Freud, who uses the dog as a substitute for his own body in his analytic relationship with H.D. "Do not touch her," Freud says, and, in terms of transference, he means do not touch me (or do not hold me back, even do not hold me back from healing you). Reframing the resurrection scene, H.D. recognises Freud's position and represents it to Kenneth Macpherson in a letter dated 15 March 1933 :

Freud is just simply Jesus-Christ after the resurrection, he has that wistful ghost look of someone who has been right past the door of the tomb, and such tenderness with such humor, he just IS all that. I am sure he IS the absolute inheritor of all that eastern mystery and majic, just IS, in spite of his monumental work and all that, he is the real, the final healer. ${ }^{12}$

Freud the untouchable, Freud the real, the final healer, Freud the analyst saying, "Do not touch." And yet, H.D. does touch - not him, but his substitute, his chow, his dear Yofi:

But, though no accredited dog-lover, I like dogs and they oddly and sometimes unexpectedly "take" to me. If this is an exception, I am ready to take the risk. Unintimidated but distressed by the Professor's somewhat forbidding manner, I not only continue my gesture toward the little chow, but crouch on the floor so that she can snap better if she wants to. Yofi - her name is Yofi - snuggles her nose into my hand and nuzzles her head, in delicate sympathy, against my shoulder. ${ }^{13}$

H.D. touches and Yofi returns H.D.'s touch; the "snuggle," the soothing nuzzle, indicating a "delicate sympathy," offers us, perhaps, the other side of the coin: the healing touch. So, Freud uses Yofi as a vehicle to simultaneously prohibit touch, and offer a certain tactile healing - do not hold me back. Freud's words to H.D. are both an invitation and a warning. This dynamic is not only played out in the relationship between H.D., Freud and his dog but is endlessly repeated in the letters H.D. sends to Bryher while she is in Vienna for analysis. In a letter dated 23 March 1933, H.D. writes: 
Nearly through the hour, papa began to cough, and Yofi came and licked his hand, a most touching spectacle, papa apologized and said did I mind? The licking took a long time, almost five minutes, solid and solemn. F. says she always does that and it is sometimes very awkward. (Letters 141)

A "touching spectacle," quite literally, Yofi's "licking" performs the healing touch on the untouching healer. This "dogged" touching between Freud, H.D. and Yofi is repeated and amplified when the analysis moves to Hohe Warte in the summer months, where Anna Freud's dog, Wolf, "barked the place down" and the "hounds" infiltrate all aspects of the analysis, "running in and out and jumping on the analysis couch to lick one all over" (9 May 1933, Letters 259). This licking all over forms part of the "corpus of tact" presented by Nancy:

A corpus of tact: skimming, grazing, squeezing, thrusting, pressing, smoothing, scraping, rubbing, caressing, palpating, fingering, kneading, massaging, entwining, hugging, striking, pinching, biting, sucking, moistening, taking, releasing, licking, jerking off, looking, listening, smelling, tasting, ducking, fucking, rocking, balancing, carrying, weighing ... ${ }^{14}$

To lick: it is a most particular form of touch - an intimate, a nurturing, moreover, a loving touch; for anthropologist Ashley Montagu, "'licking,' in its actual and in its figurative sense, and love are closely connected." ${ }^{15}$ In licking both Freud and H.D., Yofi shows her love to them, and performs their love for each other.

The extent of the role of dogs in the relationship is indicated by an incident in late May 1933. H.D. describes a fight between two of the dogs and the effect it had on Freud, who, despite deteriorating health, "flung" himself into the thick of it:

Had a terrible time yesterday. Yo-fi is back and doesn't like Lun, and flew at her in the room. We had been to the kitchen to see the pups. Freud ran like lightening and flung himself on the floor and pulled them apart, all his money fell out and Anna and the maid rushed in, Anna screaming in German of course, "pappachen beloved you shouldn't have done that," and the maid taking off Yofi in her arms like Jesus with a lamb. (18 May, Letters 292)

Her letters following this incident are nervy and distracted, concerned with Freud's illness and the situation with the dogs. Writing to Bryher on 27 May, H.D. explains: "I think the dogs got his trouble and tried to get in to us, feeling he was sick. It was horrible. Almost too much when ones own skin is peeled off' (Letters 329). The dogs, 
then, not only break into the analytic space, but also into them, into their bodies, flaying them, getting under their skins; Freud's dog transgresses the boundaries or skins that divide them from the dogs, as well as each other.

"Do not touch," Freud tells H.D., and he means more than he says. But H.D. does indeed touch, and so, moreover, does Freud. His touch is only present in fragments, and yet it is present, however displaced. For instance, he substitutes a third party another $\operatorname{dog}$ - to affect his touching of H.D.; he touches Bryher, H.D.'s lover and lifelong friend, whose pet name was "Dog," in order to make contact with H.D. In a letter to Macpherson on 14 April, Bryher writes:

I had my final interview for this visit with Dr F. to-day and he patted small dog \{Bryher $\}$ and said now he had trotted into fold he must not be allowed to run out again and that every possible influence would be used to get small dog a collar. (Letters 175$)^{16}$

"Patting small dog," Freud both conforms to and breaks his own taboo on touching his patients: he does not touch his analysand, H.D., but at the same time he does - he touches her through Bryher, in the similar way that the analytic pair exchange forbidden "gifts" through Bryher and their daughter, Perdita. ${ }^{17}$ Like touch, gifts are prohibited in Freudian analysis, but this prohibition is overcome and exchange is granted through the mediatory figures of Bryher and Perdita. ${ }^{18}$ The main economy of exchange is, of course, the dogs. Certainly, many of H.D. and Bryher's letters are concerned with Freud's offer of one of Yofi's puppies:

\section{Dawg and Dogggg.}

The worst has happened.

\section{Dandog}

Will you please put your two heads together.

I feel like the Virgin Mary at the entrance of the dove. Pa-pa has offered us one of Yo-fi's pups. What will we do about it???????????????????? (26 April, Letters 200)

In offering them the puppy, Freud is, in effect, offering them a means of permanent contact with Yofi, as well as with himself; the contract will be bound by the patting, snuggling and licking of dogs and their offspring. H.D. is not unaware of the significance of this gift, interpreting it as her impregnation by Freud: "I feel pregnant," she writes to Bryher on 27 April, just like Yofi (Letters 203). H.D., however, is 
adamant about this "touching" gift: "Evidently I was afraid of becoming pregnant by papa Freud, funny????????? But no Freud-cat, or esoteric Yo-fi, I can assure you, will be stranded on your front door step like the last one, vintage 1919" (25 April, Letters 197). ${ }^{19}$ This assurance follows a startling revelation concerning H.D.'s own fears. It seems that H.D. (whose pet name is "Cat" or "Kat") is afraid of the nature of Freud's touch; not only is she horrified to discover that Freud doesn' $t$ like cats ${ }^{20}$ but she also displays anxiety about the vicious tendency of dogs towards cats. She writes to Robert Herring, who also owns chows, about the predisposition of this breed of dogs to attack cats: "You asked me, do they kill cats," he replies, "and I say, I don't think its in them, more than other dogs ... Yo-fi I should think attacked the cat because it knows a cat goes for the eyes, and felt it had to protect the pups it was carrying - perhaps?" (n.d., Letters 235 n. 15). Although she repeatedly describes Freud as "tender" (Letters $87,100,165$ ), she also appears wary of his touch by displaying anxiety about Yofi's behaviour with a "cat." Ironically, in eventually rejecting Freud's gift, H.D. is most concerned in not hurting Freud's "feelings": "we will have to use tact" (1 May, Letters 230); it "must be done most tactfully ... above all, most tactfully" (24 May, Letters 319).

"Tact itself: a phantom touching," writes Cixous in "Love of the Wolf," alluding to the haunting that always interrupts touch. ${ }^{21}$ Steven Connor explains that "the values of tact, 'touch', subtlety, refinement and so on, all depend upon and ramify from the thought of the sensation of its particular kind of lightness of touch." ${ }^{22}$ Tact, for him, is a touch that "retracts itself, but not fully"; it gestures towards an "infinitesimal meniscus between touching and not-touching" (262). In effect, tact, as Derrida writes, warns against the excess of touch, it is a "moderation of touch," or "some kind of reserve [that] holds it on the brink of exaggeration" (On Touching 47). For Derrida, "a certain tact," moreover,

a "thou shalt not touch too much," "thou shalt not let yourself be touched too much," or even "thou shalt not touch yourself too much," would thus be inscribed a priori, like a first commandment, the law of originary prohibition, in the destiny of tactile experience. (47)

Derrida leads us by the hand back to the "law of tact" - a law that demands "one must touch without touching": 
In touching, touching is forbidden: do not touch or tamper with the thing itself, do not touch on what there is to touch. Do not touch what remains to be touched, and first of all law itself - which is the untouchable, before all the ritual prohibitions that this or that religion or culture may impose on touching, as suggested earlier. (66)

In insisting "it must be done most tactfully ... above all, most tactfully" (Letters 319), H.D. learns "how to touch without touching, without touching too much, where touching is already too much" (On Touching 67). The analysis demands that H.D must "touch him without moving him"; as Derrida says, she must touch "almost imperceptibly, intangibly" (135). In this tactful relationship, touch and untouchable collide

So, in a sense, tact involves a not-touching. As such, it exposes the space, the absence, the non-contact that haunts the fact of touching. Challenging both the privilege and the unity of touch, Derrida insists that there exists a "law of parting and sharing at the heart of touching and con-tact" (199); touch is always already inhabited by its own differ rance. I cannot touch the heart of the matter; touching you, I only ever touch the very outside of you with the very outside of me; contact is only ever at the absolute limits. Drawing attention to the heart as "absolute intimacy of the limitless secret" (267), and the fact that the heart is an "interior surface of the body" that "no "selftouching' can ever reach" (267), Derrida shows that touch always becomes its own point of non-contact, with "interruption, interposition, detour of the between in the middle of contact" (229). The most we can ever do, he says, is "touch on a surface, which is to say the skin or thin peel of a limit" (6). The limits of touch, Christopher Stokes explains, mean that the "spacing, interruption or non-contact at the heart of touching" is the very condition of touch. ${ }^{23}$ Or, as Ian Maclachlan describes it: "there can be no touching without loss of contact." ${ }^{24}$ This is because "something always intervenes to disrupt the apparent immediacy of touch, whether it be a case of touching oneself or touching the other; touching presupposes interruption, lest touch simply vanish into consubstantiality" (58). While Maclachlan does not "deny the contacts of touch," he argues that touching always presupposes interruption, and "the resistance of skin as I feel myself touch you is testimony to this interruption" (58). Touch is always already inhabited by its own "différance of the between" (On Touching 229). And it is "this elementary différance of interposition or intervals 
between two surfaces [that] is at the same time the condition of contact" (229). Touch, then, touches on the untouchable.

A "thinking of touch, this thought of what 'touching' means, must touch on the untouchable" (18), argues Derrida. This problem - "how to touch upon the untouchable" (6) - is played out in H.D.'s letters. Writing to Bryher about their terrifying housekeeper, Dorothy Hull, H.D. describes herself as "untouchable" (7 March 1933, Letters 60). And yet she tampers with her own status as untouchable even as she tenders it: "Deliver some chaste message to the $\mathrm{Q}\{$ Dorothy Hull\} from the 'untouchable.' I am so touched that P is gold-digging like mad" (Letters 42). Thus, even as she offers herself as untouchable to "the Q," she admits that she is "touched" by the behaviour of $\mathrm{P}$ - her daughter, Perdita. Her letters are certainly full of the "contradictory injunctions ... at the heart of touch" (On Touching 76); she is both touchable and untouchable, simultaneously obeying and breaking a law of tact.

H.D.'s touching untouchability extends to the possibility of touching on H.D.'s writing corpus; physically tangible, it also bears the trace of its own untouchable quality. How is it ever possible to touch through a text? "Two bodies can't occupy the same place simultaneously," writes Nancy: "Therefore you and I are not simultaneously in the place where I write, where you read, where I speak, where you listen. No contact without displacement." ${ }^{25}$ For Maclachlan, if "interruption inhabits the contact of touch," then the "possibility of touch may also inhabit the interruption of distance, for example the distance of writing." ${ }^{26}$ Referring to the "infinitesimal dust of contact" that occurs during the endlessly deferred process of reading and writing, Nancy argues:

Bodies, for good or ill, are touching each other upon this page, or more precisely, the page itself is a touching (of my hand while it writes, and your hands while they hold the book). This touch is infinitely indirect, deferred machines, vehicles, photocopies, eyes, still other hands are all interposed - but it continues as a slight, resistant, fine texture, the infinitesimal dust of contact, everywhere interrupted and pursued. ${ }^{27}$

Reading H.D., an infinitesimal dust of contact drifts between us. Zsuzsa Baross suggests, however, that a sur-text, a writing on the text of another writer, may be an unwelcome touch: 
As offering, writing ineluctably risks giving offense, an intrusive touch (whose violence the biblical usage of offense as "striking against the foot" $[O E D]$ so well preserves), sending off as it does in the direction of the other an unsolicited missive, a perhaps unwanted gift, and so far as writing, a "false" present that would never give itself completely, without reserving something for itself. ${ }^{28}$

Thus, "the ever-present danger of misappropriation by the way of the hand unlawfully grabbing, taking hold of, (another's) writing, as though 'property"' (150), renders H.D.'s writing untouchable, even as I touch upon it. Any writing, as Baross suggests of her own writing on Derrida, will have to be an "offering": "writing that approaches Derrida from a distance, writes toward him, perhaps without ever reaching him (as news or missive), perhaps without even touching him" (150). And thus, writing on H.D., I write towards her, ensuring the possibility of touching becomes ever more remote.

Neither immediate nor close, touch is filled with distance. Simultaneously performing her own desire "to touch and be touched," Cixous draws particular attention to the idea of a touch without touch, an untouchable touch, a telephonic touch: "An employee of Air France tells me on the telephone: I like your books because they touch me. We all like to touch - to be touched." 29 Touching at a distance, the telephone performs remote contact; it demonstrates that we can make contact even from afar. "One cannot imagine closer to farther," she writes in Rootprints: the telephone is "the far in the near"; it is "the outside in the inside"; the "motherdaughter" relationship. ${ }^{30}$ Thanks to the telephone, we touch without touching; "from very far, we launch the most restrained, the most murmured call" - the call that gives us the voices "that touch us most strongly" (49). They touch us from afar, up close. This telephonic touch, touching us from afar, up close, is re-enacted in H.D.'s letters through the idea of the "telegraphic" touch. In her letters she frequently refers to "wires" or telegraph messages received and sent. Regarding the puppies, H.D. writes on 26 April 1933, “Please write, don't (N.B. do not!!!) wire Freud, 'yes' as I am not sure it would be feasible. Its all you, you, you, Fido. Now Fido ... O, please I feel so very about-to-deliver" (Letters 200-01). The delivery of this telegraphic touch, like 
the delivery of her dog-baby, is, however, forever postponed in the text. Indeed, the wires referred to in Friedman's collection are often missing - they remain undelivered. On arrival in Vienna, H.D. writes to Bryher on 1 March:

I sent a wire off about 4 yesterday on arrival, as I feared I would not be able to call you up, and a wire would have been as quick. This morning a notice came that it had not been received, so I was horrified, and at once sent off another, to Macpherson, Closeup, Vevey. (Letters 25)

Bryher and Macpherson's "telegraphic address - Closeup Vevey," Bryher writes to H.D. (Letters 20), is, it turns out, not so very "closeup." 31 Haunted by the space and interruption inherent in touch - even telegraphic touch - Closeup is, rather, out of reach. Bryher writes a pressing note to H.D. on 21 March:

\section{Urgent.}

Post office has changed our telegraphic address in error to Kenwin Vevey instead of Closeup accounting for terror on your arrival. Please note in future Kenwin Vevey.

Stop Press. (Letters 131)

Even those "wires" received are absent from Friedman's collection, the wires bypassing or surpassing Friedman's hand-picked letters, remaining untouched. And yet the wires indicate a sense of urgency - they are quite "frantic" (Letters 64); displaying a certain nakedness, they undress the text. And it is returning to this naked voice that we find ourselves, once again, back in the realm of touch - a word, a letter, a wire, a gift - that touches. This demonstrates that while the hand cannot make complete contact, perhaps the written word can make a different gesture towards the untouchability of touch, moving towards an alternative, textual touch - a remote touch that functions through distance. H.D.'s poetics, I propose, are haunted by this remote touch. Rethinking contact through the written word, the second part of this paper moves on to examine the ways in which H.D.'s poetry inspires a new tact.

Derived from the French touche or toucher, the word "touch" not only refers to physical contact with the surface of our body but is also inextricably bound up with 
the notion of "feeling" and the emotionally affective (or "touchy feely") implications that this word implies. And yet touch refuses to be fixed in semantics; it is hard to put our finger on touch, hard to get a hold of it. Indeed, as Montagu notes:

Interestingly enough, when one consults a dictionary for the various meanings of the word one finds that the entry under "touch" is likely to represent the most extensive in the volume. It is by far the longest entry - fourteen full columns - in the magnificent Oxford English Dictionary. This in itself constitutes some sort of testimony to the influence which the tactile experience of hand and fingers has had upon our imagery and our speech. ${ }^{32}$

Attempting to define touch, we move in multiple directions, not only towards physical sensation but also towards emotion and through language too. A lexicon of touch has entered our everyday language through the expression of an emotional or aesthetic experience; a "deeply felt experience is 'touching"" (6), for instance. The reciprocal relationship between sensation and feeling is also illustrated in H.D.'s letters to Bryher. In a single letter, dated 15 March 1933, H.D. writes, "About your coming on here ... I am really terribly touched" (Letters 95). She goes on: "Now it is really touchingly sweet of you, darling Fido, to say you will come through. I will 'hold the right thought' and if it happens, it will be marvellous" (95), not only repeating the touching metaphor but also extending it through the act of "holding." And again, in the same letter, recounting a story of "Papa" (Freud) and Yofi, she describes it as "all very funny and touching" (96). In other ways, too, her writing exhibits a lexicon of touch: H.D. refers to getting "in touch with 'events,' if you like" (231); she is "not afraid (touch wood) of war" (283); she feels "very tender toward" England (284); and when offered a chow puppy from Freud, as I have already noted, suggests that "the only thing is to hold it over tentatively" (235) ... and, of course, "above all, most tactfully" (319).

If touch and feeling can be brought together through language, it is especially interesting to think about the ways in which language can touch us, can make us feel. In conversation with Gilbert Tarrab and reiterating the prohibition of touch in psychoanalysis, Anzieu argues: "Experience shows me that it is sufficient to resort to symbolic touching: one can touch with the voice." 33 Words, then, have the power to touch us; they can function as symbolic touch experiences - a remote experience of touch that inspires "feeling" without bodily contact. In suggesting this, Anzieu draws 
on Montagu's description of infant development, whereby the original sensation of being held by the caregiver is gradually replaced through language: "The rhythm of this kind of tactual stimulation that the mother conveys to the child in her arms is almost universally reproduced in the lullabies sung or hummed to lull children to sleep" (119). Substituting the physical act of holding with a web of words, the voice becomes a surrogate for touch; words seem "up close and personal" without actually being "closeup," as in H.D.'s missing wires to Vevey. Both Montagu and Anzieu, however, in discussing the tactile properties of language or the symbolic experience of touch through the voice, are referring to the spoken word. I propose instead that we can take the notion of "symbolic touching" beyond the verbal by considering the remote tactility of the written word, primarily the tactile poetics of literature. I refer here to the way in which the written word can function as a symbolic touch experience; the ways in which literature can "touch" us too.

The tactile capacity of the written word is especially emphatic in the writings of Cixous. In "Writing Blind," Cixous makes the power of literature to touch explicit: "I like your books because they touch me" (188). Indeed, Cixous - well aware of the power of writing to "move me, touch me, strike me with blows of the axe"34 - claims in "Writing Blind" to write in order to actually touch the limits: "I do not write to keep. I write to feel. I write to touch the body of the instant with the tips of the words" (195). Touching the tips of words, Cixous puts into play what Anzieu merely describes: not only does the spoken word have the power to touch, but writing can touch us too.

H.D., I propose, was profoundly aware of the power of writing to touch. In her early poem, "The Pool," she alludes to the sense of touch and its relation to creativity:
Are you alive?
I touch you.
You quiver like a sea-fish.
I cover you with my net.
What are you - banded one ${ }^{35}$

Following Donna Hollenberg, who suggests that "The Pool" conveys "the primordial, undifferentiated quality of creativity," $" 36$ this poem, like many others, deals with a struggle with authorship and identity and exposes the writer's desire to "touch" the 
reader, even to get in touch with a reader through language rather than physical contact. Referring to both sexuality and her identity as a writer, H.D.'s poem addresses not only a pool of water but also a pool or well-spring of creativity. Thus, in writing "The Pool," she conjures the (im)possibility of the written word to touch, perhaps even to penetrate the depths of this pool of literary creativity, causing it to "quiver like a sea-fish." The pool, however, is both reflective and bottomless, both real and imaginary. As Hollenberg remarks: "In very few lines 'The Pool' deftly calls on our sense of touch to convey the elemental quality of water (and the unconscious) together with its impenetrable mystery" (75). The depths of this pool are always already untouchable, and her touch, therefore, can only touch its most "sensitive point" - its outside limit, its edge, its skin.

H.D. takes this idea of touching the untouchable in a different direction in "Amaranth" (CP 310-15). This poem is reputedly, with "Eros" and "Envy," one of a triad of poems narrating the breakdown of her relationship with Richard Aldington. The three poems seem to mark a shift towards a more "tactile" writing in H.D.'s oeuvre, so that she is not only describing "touch" as in "The Pool" but she is, moreover, performing it. "Amaranth" voices the move away from an "indifferent" Greek dramatic mask towards a more personal and feeling writing voice ${ }^{37}$ Reportedly referring to H.D.'s reluctance to touch or be touched by her husband following the stillbirth of her first child and the doctor's severe warnings regarding a repeated wartime pregnancy, the narrator's cry to her lover in "Amaranth" is that she was not frigid to his touch: "I tell you this: / I was not asleep" (CP 311). She insists,

I was not dull and dead when I fell back on our couch at night. I was not indifferent though I turned and lay quiet.

I was not dead in my sleep. (312)

She is, rather, utterly feeling - sensing "flesh ... scorched and rent, / shattered, cut apart, / and slashed open' (311). These words capture a physicality of experience; although she lies quiet, she finds

my heels press my own wet life

black, dark to purple

on the smooth rose-streaked 
threshold of her pavement. (311)

This writing begins to demonstrate what I refer to as tactile poetics. Her words seem to have a material power - they have a physicality of their own, they make us "feel" from a distance. By this, I do not only mean that her writing is emotionally affective, nor do I solely refer to the fact that this writing "touches" on the body and draws the female bodily experience to the forefront of the poem. Rather, I argue that H.D.'s writing has the capacity to generate a tactile experience in the reader through the rhythm and the resonance of the poem. I "feel" the words on the inside of my body, under my skin. This follows Nancy's insistence:

(I won't bother arguing that I'm not praising some dubious "touching literature." I know the difference between writing and flowery prose, but I know of no writing that doesn 't touch. Because then it wouldn't be writing, just reporting or summarizing. Writing in its essence touches upon the body.) ${ }^{38}$

For Nancy, "touching upon the body, touching the body, touching - happens in writing all the time" (11). H.D.'s writing, it seems to me, draws this tactility to the surface; her works are invested, inhabited, even haunted by a feeling that touches the limits of felt experience. H.D.'s "Amaranth" is an example. Within this poem I feel the "quiet / where the fir-trees / press" (CP 15) and the light swaying of the poem's own rhythmic architecture. The combination of text and space, of word and breath, of press and sway, fill me like music. It is this musical quality that touches me, that makes me feel.

In Rootprints, Cixous argues that "the texts that touch me the most strongly, to the point of making me shiver or laugh, are those that have not repressed their musical structure" (64). She clarifies:

I am not talking here simply of phonic signification, nor of alliterations, but indeed of the architecture, of the contraction and the relaxation, the variations of breath; or else of what overwhelms me with emotion in the text of Beethoven, that is to say the stops, the very forceful stops in the course of a symphony. (64)

In drawing attention to the breath of writing - its contraction, relaxation and emotion, Cixous alludes to what Julia Kristeva refers to as the "semiotic" in writing. Language, for Kristeva, operates in two ways within the signifying process: one, as an ordered 
expression of meaning (the symbolic), as in scientific discourse; and two, as a discharge of the subject's pre-verbal energy and drives (the semiotic) ${ }^{39}$ The semiotic, which Kristeva later describes as introducing "wandering or fuzziness into language," ${ }^{40}$ is the heterogeneous modality that engages extra-verbal bodily energy and affect, allowing feelings and unconscious energy a place in the signifying process. It is present in the babble, rhythm and echolalias of infants, and also through the rhythms and glossolalias evident in psychotic discourse. At the limit or skin of language, the semiotic "produces not only 'musical' but also nonsense effects," thus challenging "accepted beliefs and significations" (133). By paying attention to the semiotic in writing - by getting "in touch" with the body's pre-verbal drives, pulsions and natural rhythms - the writer is more able to make contact with the limits of felt experience and thus touch (without touching) the reader. The semiotic, consequently, is a vehicle for tactile poetics

It is evident that in her transition from "H.D. Imagiste," as Ezra Pound named her in $1912,{ }^{41}$ to the H.D. writing late poems such as "Sagesse" in 1957, H.D. increasingly opened up her own writing process to the semiotic modality. ${ }^{42}$ Interestingly, in this late poem, H.D. returns to the image of the pool, making it a significant point of comparison. Whereas the "crystalline" form of her earlier imagist writing did not fulfil her principles - "I have never been completely satisfied with any of my books, published or unpublished," she recalls of her pre-Freud work ${ }^{43}$ - her later approach enabled her "a deeper, more probing daemonic drive." 44 Thus, we move away from the tight and precise structure of the first "pool," and in "Sagesse," we find another one that asks questions of itself, one that touches on its own existence, one that "quivers" once again with its own semiotic resonance as it threatens to flood its boundaries:

Or is it a great tide that covers the rock-pool so that it and the rock are indistinguishable

from the sea-shelf and are part of the sea-floor though the sea-anemone may quiver apprehensively

and the dried weed uncurl painfully and the salt-sediment rebel, "I was salt, a substance, concentrated, self-contained, 
am I to be dissolved and lost?" ("Sagesse" 67)

Quite literally allowing the intertextual skin of her first "pool" to get under the skin of this pool, she refers to the "quiver" resulting from her first touch: "I touch you" (CP 56), but this time, her palimpsestic touch is permeated with its own differance. It is by inviting extra-verbal bodily energy and affect into her later writing that she allows the semiotic to enter her own signifying process, generating a poetic that, as Cixous might say, touches "the body of the instant with the tips of the words." 45 This time, H.D. does not say "I touch you"; rather, her writing performs this untouchable touch for her.

"Sagesse," from "Sageness, profound wisdom" $(O E D)$, was written just a few years before H.D.'s death, and subtly demonstrates a Kristevan dialectic between the semiotic and the symbolic in order to offer a new, tactile poetic. The voice in the poem alternates between that of an adult and that of a child in wartime, playing, as Pearson describes, "back and forth between the scenes of the child and her family in London, and the scenes in the sanitarium [sic] at Küsnacht" (viii), where H.D. spent the last years of her life. For Hollenberg, this adult-child dialectic

dramatizes the restorative effect of the preoedipal mother upon the imagination of the poet-daughter by showing how the inner colloquy of the poet reproduces the empathy between mother and child that is broken by an awareness of the father and the male order of language. (216-17)

In other words, the poem dramatises a dialogue between the semiotic (what Hollenberg calls the "preoedipal mother") and the symbolic ("awareness of the father and the male order of language"). Consisting of twenty-six parts, the poem begins as the first narrator opens a copy of The Listener on 9 June and sees " "a white-faced Scops owl from Sierra Leone, / West Africa"” ("Sagesse" 58). This image takes the narrator both forward in time to her "imprisonment," like the owl, in the sanatorium following a broken hip, and backwards, to wartime London during her childhood. Allowing these childhood associations to rise up through her poetry, the narrator now sees the owl as " comical, his baggy trousers / and spindly legs - you've still got half a bun"" (60). The child's father, insisting that the owl "won't eat buns ... but mice and such," compares him to "Guy" (Fawkes):

the child remembers something, draws away, 
she thinks, "I never saw a farthing,

it's half a ha'pence, but she said, teacher or somebody, or Mr. Spence, that there were two, not owls,

some other birds, sold for a farthing - and what else?" (60)

In giving voice to the child's perspective, these associations unsettle the idea of a single, fixed meaning of the owl in captivity - and, furthermore, a "God" that would allow such imprisonment. Thus, in describing a vulnerable child who "may shudder" at the image of the caged owl, H.D. uses the revolutionary potential of the poetic to unsettle our idea of how language works to produce meaning.

The child's voice, it appears initially, enables H.D. to engage with the semiotic and invests her writing with a pre-verbal bodily energy that enlivens the poem. Indeed, as the poem progresses, the semiotic - with its rhythms and associations - increasingly resonates through the child's narrative:

"yes, they're pretty, mum, the deers" - does it mean animals? does He run, too, on little hooves like that one, does He jump and stand (now) like the biggest one with horns,

straight up against the wire? (62)

In response to the unsettling idea of the owl for the child, and the power of a God to allow its captivity, the "adult" narrator appeals to a multitude of angels. "Tara," "Dieu fontaine de sagesse," and "Ptébiou" are, as Hollenberg explains, "guardians and protectors who exist outside of the conventional Judeo-Christian script for men and women" (217). Thus, in appealing to figures from the occult, H.D. begins also to disturb the symbolic order of the adult voice in the poem - an accepted world of Christian mythology, where Noli me tangere still prevails. Allowing the symbolic to touch on or rub up against the semiotic, H.D. hands over the touching dialectic to the reader.

The revolutionary semiotic present within the adult voice strengthens as the poem develops: 
and Sister Annie brings my coffee,

and I say, "how are you?" and she says, "gut - gut";

Goot and Goed, Scotch and Belgium, my book says,

Goot, gut and good and surely God, and so we play

this game of affirmations and of angels' names,

this Sunday, one week after Whitsun. (63)

This wordplay continues - “'gut - gut,' I'll say and Goot will surely answer; / God who receives sinners? What are we? / and Goed is 'gut,' actually some say 'goed' here" (63) - until we find ourselves with "Goth, Gott, Germain" (64). Germain modelled on the young German psychiatrist Dr Erich Heydt, who often visited H.D. at the clinic - enters the poem through free-associative wordplay. Ironically, therefore, the male doctor - a figure of authority and order - is made present through H.D.'s use of the maternal semiotic. This wordplay leads to an almost manic repetition of the guttural "g” sound - "God" (59), "glare" (68), "ghostly" (59), "gladness" (59), "go" (60), "Guy" (60), "great" (67), "Grande Mer" (73) "Gawd" (77), to name a few. We might consider the "g" as a glottal sound - "an expulsion of air animated by the sphincters at the rear of the throat ... echoing a coughing movement of expectoration," as Leslie Hill explains in relation to Samuel Beckett's use of the letter "g". ${ }^{46} \mathrm{G}$ - God, Grandmother (which H.D. then was) - also leads us to gram, to glyph, graphic, gone. The glottal sound, furthermore, makes reading the poem a very physical experience, with the most untouchable word - "God" - in our throats as we utter the name. The letter $\mathrm{G}$, moreover, is contrasted with the sibilance of the " $\mathrm{s}$ " in "Sagesse": "Sotis, Sothis, Sith" (70). Indeed, the first eight lines of Part 19 are, in particular, littered with the "s" sound: "strand"; "72"; "seventh"; "Senciner"; "Seket"; "started"; "compassed"; "closed"; "circle" (76). On one level, the soft "s" and the guttural "g" sounds truly make this a tactile poem to read. On another level, as Hollenberg notes, the "chain of word origins and word--sound associations afford[s] H.D. a liberating departure from the male symbolic order" (219). Troubling the symbolic order, "Sagesse" demonstrates a jouissance associated with the semiotic modality. H.D.'s poetry is, in a Kristevan sense, revolutionary - and her use of the letters "s" and "g" make it a particularly "tactile" piece of writing. The poem unsettles the symbolic order, demonstrating the revolutionary power of poetry - its power not only to "touch" us but to "move" us in new directions too. Ending with a most 
touching laughter - a laughter as remains ${ }^{47}$ - "laugh the world away, / laugh, laugh" (84) - "Sagesse," as Hollenberg suggests, recovers "what Kristeva calls 'the riant wellsprings of the imaginary' or 'riant spaciousness,' a joy without words that she will reinvest in the production of the new" (222-23). This laughter invites us to return to the semiotic origins in order to reinvest in the production of the new, to open ourselves to the future, to the "something to come [il y a de l'avenir]."48

It is by opening up to "something to come" that I attempt to end this paper on touch by touching touch. Trying to touch touch, we come face to face - or hand to hand with its unique reflexivity:

Touch is the only one of the five external senses which possesses a reflexive structure: the child who touches the parts of its body with its finger is testing out the two complementary sensations, of being a piece of skin that touches at the same time as being a piece of skin that is touched. ${ }^{49}$

Thinking through the unique reflexivity of the sense of touch - our ability to touch and be touched simultaneously, Derrida seizes the way in which the verb to touch in the French language is itself reflexive - se toucher, to be touched, to touch itself, to self-touch - even, to self-touch you. Describing it as a "strange tautology," Derrida notes the "grammatical reflexivity" of "self-touching" in the figure of the kiss, which he allows "to oscillate from one to the other (touching oneself or touching each other?)" (On Touching 274, 270). Indeed, se toucher, the self-touch, for Derrida, is the very condition of sense, and "to be means to touch and to touch touch" (275). Thus, if words are symbolic touch experiences, how do I "touch on" this? How do I touch touch? Is it, finally, ever possible to make contact?

Rather than closing down my discussion of touch, the untouchable in touch, instead, opens up to something new, something to come. As Stokes explains in his review of Derrida's text, "a philosophy which acknowledges its own lack of mastery, its own inability to touch, opens itself up to the other" (372). This is precisely what this essay attempts to do. Opening itself up to the other, this paper invites you to touch its skin. It asks its readers to make contact, to seize the tactile poetics in literature, and to write "closeup," from afar. 


\section{Notes}

My thanks to reviewer Sarah Wood for her helpful comments on this article.

1 H.D., Tribute 98.

2 According to H.D., the first thing Freud says to her is "You are the only person who has ever come into this room and looked at the things in the room before looking at me" (ibid.).

3 Freud, Studies on Hysteria II: 49; hereafter parenthesised as SE.

${ }^{4}$ For a history of Freud's use of touch, see Smith; and Beckenridge. For touch in psychotherapy more generally, see Older.

During later hypnosis, Freud discovered that her strange demands "related to the fact that the animal shapes which appeared to her when she was in a bad state started moving and began to attack her if anyone made a movement in her presence" (SE II: 56). The "final injunction 'Don't touch me!,", Freud explained, derived from an experience when her brother, unwell from too much morphine, would "seize hold of her" (56)

Jones 448.

7 Anzieu, The Skin Ego 139.

8 Derrida, On Touching 66

9 John 20.17.

10 Nancy, Noli Me Tangere 12. Reflecting on the many ways that "Noli me tangere" has been interpreted in the arts and medicine, Nancy insists, "Few phrases from the Gospels have been so widely disseminated" (109). For further readings of Christ's prohibition on touch, see Baross; Derrida, On Touching; and Manning.

11 Matt. 8.3 cited in Derrida, On Touching 100.

12 Friedman, Analyzing Freud: Letters of H.D. 100; hereafter parenthesised as Letters. Following Friedman, I present these letters without correction to spelling or grammar.

13 H.D., Tribute 98.

14 Nancy, Corpus 93

15 Montagu 28-29.

16 The dog collar refers to Bryher's desire for acceptance into the psychoanalytic fold.

17 Perdita Macpherson Schaffner (born Frances Perdita Aldington), H.D.'s daughter to Cecil Gray, was adopted by Bryher and Macpherson.

18 See Letters 192-93.

19 Referring to Perdita's adoption.

20 See Letters 52.

21 Cixous, "Love of the Wolf" 124.

22 Connor 259.

23 Stokes 370 .

24 Maclachlan 58.

25 Nancy, Corpus 57

${ }^{26}$ Maclachlan 58

27 Nancy, Corpus 51.

28 Baross 150.

29 Cixous, "Writing Blind" 188.

30 Cixous with Calle-Gruber 49.

31 "Closeup" refers to cinema's first art journal, edited by Macpherson (and greatly aided by H.D.).

32 Montagu 102.

33 Anzieu, $A$ Skin for Thought 78-79.

34 Cixous, Three Steps 36.

35 H.D., "The Pool" in Collected Poems 56; hereafter parenthesised as CP.

${ }^{36}$ Hollenberg 75

37 See Martz's account of H.D.'s shift away from Imagist principles and Greek mythology (xix).

38 Nancy, Corpus 11. 
39 See Kristeva's Revolution in Poetic Language 34.

40 Kristeva, Desire in Language 136.

41 See Pound.

${ }^{42}$ H.D., "Sagesse" in Hermetic Definition.

43 H.D., Tribute 148.

${ }^{44}$ Pearson $\mathrm{v}$.

${ }^{45}$ Cixous, "Writing Blind" 195.

46 Hill cited in Katz 31.

47 "It remains perhaps to think of laughter, as, precisely, a remains. What does laughter want to say? What does laughter want? [Qu'est-ce que ça veut dire, le rire? Qu'est-ce que ça veut reire?]" (Derrida, "Ulysses Gramophone" cited in Royle 64).

48 Derrida and Ferraris 13.

49 Anzieu, The Skin Ego 61-62.

\section{Bibliography}

Anzieu, Didier. The Skin Ego. Trans. Chris Turner. New Haven and London: Yale UP, 1989.

Anzieu, Didier. A Skin for Thought - Interviews with Gilbert Tarrab on Psychology and Psychoanalysis. Trans. Daphne Nash Briggs. London and New York: Karnac, 1990.

Baross, Zsuzsa. "Noli Me Tangere: For Jacques Derrida." Angelaki 6.2 (2001): 149-64.

Beckenridge, Kati. "Physical Touch in Psychoanalysis: A Closet Phenomenon?" Psychoanalytic Inquiry 20.1 (2000): 2-20

Cixous, Hélène. "Love of the Wolf." Trans. Keith Cohen. Stigmata: Escaping Texts. London and New York: Routledge, 2005. 110-130.

Cixous, Hélène. Three Steps on the Ladder of Writing. Trans. Sarah Cornell and Susan Sellers. New York: Columbia UP, 1993.

Cixous, Hélène. "Writing Blind: Conversation with the Donkey." Trans. Eric Prenowitz. Stigmata: Escaping Texts. London and New York: Routledge, 2005. 184-203.

Cixous, Hélène with Mireille Calle-Gruber. Hélène Cixous - Rootprints: Memory and Life Writing. Trans. Eric Prenowitz. London: Routledge, 1997.

Connor, Steven. The Book of Skin. London: Reaktion, 2004.

Derrida, Jacques. On Touching - Jean-Luc Nancy. Trans. Christine Irizarry. Stanford: Stanford UP, 2005.

Derrida, Jacques. "Ulysses Gramophone: Hear Say Yes in Joyce." Trans. Tina Kendall and Shari Benstock. Acts of Literature. Ed. Derek Attridge. London and New York: Routledge, 1992. 256-309. 
Derrida, Jacques and Maurizio Ferraris. A Taste for the Secret. Trans. Giacomo Donis. Malden, MA: Polity, 2001.

Freud, Sigmund. Totem and Taboo and Other Works. 1913. The Standard Edition of the Complete Psychological Works of Sigmund Freud. Vol. XIII. Ed. James Strachey. Trans. James Strachey with Anna Freud, Alix Strachey and Alan Tyson. London: Vintage, 2001.

Freud, Sigmund and Josef Breuer. "Case Histories." 1895. Studies on Hysteria. The Standard Edition of the Complete Psychological Works of Sigmund Freud. Vol. II. Ed. James Strachey. Trans. James Strachey with Anna Freud, Alix Strachey and Alan Tyson. London: Vintage, 2001. 19181.

Friedman, Susan Stanford (ed.). Analyzing Freud: Letters of H.D., Bryher, and their Circle. New York: New Directions, 2002.

H.D. Collected Poems 1912-1944. Ed. Louis L. Martz. New York: New Directions, 1983.

H.D. Hermetic Definition. Oxford: Carcanet, 1972.

H.D. Tribute to Freud: Writing on the Wall \& Advent. Manchester: Carcanet, 1985.

Hill, Leslie. Beckett's Fiction: In Different Words. Cambridge: Cambridge UP, 1990.

Hollenberg, Donna Krolik. H.D.: The Poetics of Childbirth and Creativity. Boston: Northeastern UP, 1991.

Jones, Ernest. The Life and Work of Sigmund Freud. Volume 2. Years of Maturity, 1901-1919. London: Hogarth, 1955.

Katz, Daniel. Saying I No More: Subjectivity and Consciousness in the Prose of Samuel Beckett. Evanston, IL: Northwestern UP, 1999.

Kristeva, Julia. Desire in Language: A Semiotic Approach to Literature and Art. Ed. Leon S. Roudiez. Trans. Thomas Gora, Alice Jardine and Leon S. Roudiez. Oxford: Blackwell, 1980.

Kristeva, Julia. Revolution in Poetic Language: The Portable Kristeva. Ed. Kelly Oliver. New York: Columbia UP, 2002.

Maclachlan, Ian. "Long Distance Love: On Remote Sensing in Shakespeare's Sonnet 109." Sensual Reading: New Approaches to Reading in its Relations to the Senses. Ed. Michael Syrontinski and Ian Maclachlan. Lewisburg: Bucknell UP, 2001. 57-66.

Manning, Erin. Politics of Touch: Sense, Movement, Sovereignty. Minneapolis and London: U of Minnesota P, 2007. 
Martz, Louis L. "Introduction." Collected Poems 1912-1944 by H.D. New York: New Directions, 1983. xi-xxxvi.

Montagu, Ashley. Touching: The Human Significance of the Skin. 2nd ed. New York: Harper, 1978.

Nancy, Jean-Luc. Corpus. Trans. Richard A. Rand. New York: Fordham UP, 2008.

Nancy, Jean-Luc. Noli Me Tangere: On the Raising of the Body. Trans. Sarah Clift, Pascale-Anne Brault and Michael Naas. New York: Fordham UP, 2008.

Older, Jules. Touching is Healing. New York: Stein, 1982.

Pearson, Norman Holmes. "Foreword". Hermetic Definition by H.D. Oxford: Carcanet, 1972. v-viii.

Pound, Ezra. "A Retrospect." Literary Essays of Ezra Pound. London: Faber, 1954. 3-14.

Royle, Nicholas. After Derrida. Manchester: Manchester UP, 1995.

Smith, Edward W.L. "Traditions of Touch in Psychotherapy." Touch in Psychotherapy: Theory, Research and Practice. Ed. Edward W.L. Smith, Pauline Rose Clance and Suzanne Imes. New York and London: Guilford, 1998. 3-15.

Stokes, Christopher. "Review of Jacques Derrida's On Touching - Jean-Luc Nancy." Textual Practice 20.2 (2006): 370-73.

Sarah Jackson

Nottingham Trent University

Clifton Lane

Nottingham NG11 8NS

UK

E-mail: sarah.jackson02@ntu.ac.uk 